DOI: $10.24000 / 0409-2961-2021-1-46-52$

\title{
Simulation of a breathing apparatus on chemically bound oxygen with a circular pendulum circuit of the air duct part
}

Ekhilevskiy, S.G.,

Golubeva, O.V.,

Potapenko, E.P.

Ехилевский С.Г., Голубева О.В., Потапенко Е.П. Моделирование дыхательного аппарата на химически связанном кислороде с кругомаятниковой схемой воздуховодной части// Безопасность труда в промышленности. — 2021. — № 1. — C. 46-52. DOI: 10.24000/04092961-2021-1-46-52

Аннотация:

В настоящее время основные перспективы совершенствования изолирующих средств защиты органов дыхания связаны с химическим способом резервирования кислорода. Аргументами в пользу такого выбора являются высокая плотность упаковки кислорода и его саморегулирующаяся подача в зависимости от фризической активности человека. Основными схемами воздуховодной части дыхательных аппаратов на химически связанном кислороде являются круговая и маятниковая. В статье предпринята попытка объединить достоинства круговой (малое вредное пространство) и маятниковой (малый объем мертвого слоя) схем дыхательных аппаратов на химически связанном кислороде.

В этих целях развит метод формализма, позволяющий математически и с помощью компьютера моделировать динамическую сорбционную активность регенеративного патрона дыхательного аппарата с гибридной (кругомаятниковой) схемой воздуховодной части. Определен прирост защитного действия аппарата, обусловленный использованием ресурса мертвого слоя сорбента в результате реверса воздушного потока в маятниковой части регенеративного патрона. Показана целесообразность использования гибридной схемы в самоспасателях с небольшим сроком защитного действия. Определена оптимальная длина маятниковой части, при которой снижается 
сопротивление дыханию и не увеличивается вредное пространство, занятое воздухом, возвращающимся на вдох без контакта с непрореагировавшими слоями кислородсодержащего продукта. Показана ее слабая зависимость от общей длины регенеративного патрона и предельно допустимой концентрации углекислого газа в возвращающемся на вдох воздухе, что делает кругомаятниковую схему реализуемой на практике.

Список литературы:

1. Изолирующие дыхательные аппараты и основы их проектирования: учеб. пособие/ С.В. Гудков, С.И. Дворецкий, С.Б. Путин, В.П. Таров. - М.: Машиностроение, 2008. - 188 с.

2. Диденко Н.С. Регенеративные респираторы для горноспасательных работ. - М.: Недра, 1990. - 160 с.

3. А.с. 1785712 СССР. А 62 В 7/08. Изолирующий дыхательный аппарат/ Н.С. Диденко, Т.Е. Инденбаум, С.И. Фастивец; заявл. 26.11.1990; опубл. 07.01.1993, Бюл. № 1.

4. Пат. 47440 Украина. А 62 В. Ізолюючий дихальний апарат/ С.Г. Єхилевський, В.В. Пак, Е.Г. Ільїнський; опубл. 15.07.2002, Бюл. № 7.

5. Жуховицкий А.А., Забежинский Я.Л., Тихонов А.Н. Поглощение газа из тока воздуха слоем зернистого материала// Журнал фиизиеской химии. - 1945. - Т. 19. - Вып. 6. - С. 253-261.

6. Моделирование работы изолирующих аппаратов на химически связанном кислороде/ А.А. Кримштейн, С.В. Плотникова, В.И. Коновалова, Б.В. Путин// Журнал прикладной химии. - 1992. T. 65. - № 11. - С. 2463-2469.

7. Математическая модель рабочего процесса изолирующего шахтного респиратора/ В.В. Пак, С.Г. Ехилевский, В.К. Овчаров, А.Э. Ильинский// Известия высших учебных заведений. Горный журнал. - 1994. - № 1. - С. 54-57.

8. Майстренко А.В., Майстренко Н.В., Ерохин О.И. Моделирование изолирующих дыхательных аппаратов на химически связанном кислороде// Научные ведомости Белгородского государственного университета. История. Политология. Экономика. Информатика. - 2014. — № 1 (172). — Вып. 29/1. - С. 81-87.

9. A Method for the Development of Self-Contained Breathing Apparatus Using Computer Modeling/ V.G. Matveikin, E.N. Tugolukov, S.Y. Alekseyev, A.Y. Zakharov// International Journal of Engineering and Technology. - 2018. - Vol. 7. — № 3. - P. 481486. 
10. Ехилевский С.Г., Голубева О.В., Потапенко Е.П. Влияние начальной загрязненности регенеративного патрона на работу шахтного респиратора на химически связанном кислороде// Известия высших учебных заведений. Горный журнал. - 2014. - № 8. - С. 37-43.

11. Значения феноменологических параметров модели хемосорбции в регенеративных патронах шахтных респираторов/ В.В. Пак, С.Г. Ехилевский, Э.Г. Ильинский, Е.И. Конопелько// Известия высших учебных заведений. Горный журнал. - 1998. - № 11-12. - С. 108-112.

12. Ехилевский С.Г. Нестационарная задача динамики сорбции углекислого газа в регенеративном патроне изолирующего респиратора// Вестник Фонда фундаментальных исследований. - 2019. — № 3 (89). - С. 57-65.

13.Изолирующий самоспасатель для эвакуации людей при пожаре/ Л.А. Зборщик, Р.С. Плетенецкий, В.В. Говжеев, В.И. Францев// Научный вестник НИИГД «Респиратор». — 2017. — № 1 (54). - С. 102-109. 